\title{
2020: COVID-19 \& International Higher Education
}

\author{
Rosemary Gillett-Karam \\ Morgan State University, USA
}

\begin{abstract}
In this study, international students are portrayed as they present themselves now and as they have been affected and effected by the COVID-19 pandemic. Universities and colleges are featured as they react and explain their reactions, dicta, and information concerning the status of international students at their institutions. Critical to the study is that it tells the story of international students studying abroad both directly from their impressions and according to the university and college policy provided to them. Of particular interest to both reactors is the focus on offering online courses to students, which generally has received acceptance but with negative reactions. Of concern is the impact of using technologies when poor countries may not even have broadband or are mired in political decisions about technology use. No permanent solutions to the introduced issues are offered as the pandemic is a continuing with little agreed upon understanding about its permanence.
\end{abstract}

Keywords: COVID-19, international students, higher education

Serious and prolific attempts have been made to help world citizens understand the seriousness of the COVID-19 pandemic. But solutions to issues, even after several months of reports of huge numbers of cases and deaths, remain scattered and inexact. Worldwide deaths are significant, as 
cures or vaccines are not forthcoming. Hospitals suffer from understaffing, underfunding, and overworking; they are unable to receive needed and necessary medical supplies. Little practical information, beyond government orders, have satisfactory effects on COVID-19 knowledge. Words like "shelter in place, stay six feet apart, wear masks, wash hands often" while originally followed, all too soon became impossible to maintain for large numbers of peoples. They had no jobs, no income, and came to reason that there was no hope that normalcy would re-emerge. Their emotional anxieties were neither understood nor ameliorated.

Many people, including the millions of higher education students, began to take responsibility for their own health, and decided not to 'obey' dictates from confusing patterns of dictates, especially from highest government officials. As predicted, by early summer, 2020, infections from COVID-19 began to rise, especially in states and countries that had "opened up." Students, suffering from their reprieves from higher educational institutions, began once again to gather, party, and fall victim to the disease. Into this story of the affects and effects of the COVID19 pandemic; questions abound about a particular group of students--international students "stuck" in place in world-wide universities and colleges.

\section{MAIN ARGUEMENT/LITERATURE}

By March 2020, colleges in the US and abroad shut down their services from in-place, onsite course delivery in senior universities and community colleges. And as public colleges include 15 million students (six million of whom attend community colleges) concern began to grow (for example, for the 1.1 million international students, or $5.5 \%$ of the total population of students in the US) studying in US higher education institutions (Zhou, 2020). Foreign nationals were not allowed to return home, and in many cases, their own homeland institutions had difficult internal issues as well and had difficulty proposing solutions for college-aged students and their homeland return. American students studying abroad had similar issues.

Not much is known about the programs and policies put in place by higher education institutions to address foreign nationals in universities and colleges, except for publishing often unclear directives to aid such students about their living/housing conditions. Consistent eating discussions revealed yet another story-it is unclear that food services or food pantries are available to in-place foreign nationals. Policies about use of health facilities use for foreign nationals are scattered, even though there is some focus on mental health issues. Safety issues remain unsolved. Although faculty members have been instrumental in some aid, the overall picture for foreign 
nationals is bleak. Some colleges and universities have proposed moving foreign nationals to other institutions (Altbach \& de Witt, 2019). Most critical among institutional issues is the loss of revenue from such students in terms of reimbursements, course loads, and course completion. What is uppermost in the minds of many higher education administrators and their institutions is that the revenue from foreign nationals to the institution is anywhere from three to eight times higher than for indigenous citizens. For example, this figure has an impact on the banking revenue to higher education institutions who can multiply tuition resources for international students three to eight times an American student's tuition. In Great Britain and among private institutions, this loss of revenue is significantly higher than in the United States.

As higher education moved almost immediately to remote and online courses development, foreign nationals were not part of that dialogue or that decision, as language issues are only one part of that formula. Foreign students write they are "shattered," and that their shattered fallout has affected them physiologically, mentally, and emotionally. Data have not been gathered or reconfigured to address their academic or personal success. American institutions did depend on their faculty who offered online or remote courses as quickly as a course could be realigned from onsite delivery, although often deficit in quality. Difficulties occurred in classes with physiological needs (physical education, dance, labs) and from science programs that require lab results, from chemistry courses that expect consistent and logical input requiring classroom and lab aids from graduate students.

We wondered if these issues were consistent abroad as well as in the

US. The German Academic Exchange Service (DAAD, https://www.daad.de/en/coronavirus/) provided a comprehensive guide to the COVID-19 research and expertise in international higher education. It is fair to say that researchers and college-university spokespersons are plentiful in their attempts to explain the effects of COVID-19 on international countries, including their administrators, faculty, and students. Several primary considerations are discussed, beginning with actual numbers of students. China, India, and South Korea have the most enrolled international students (370,000; 175,000; and 60,000 respectively); Saudi Arabia, Brazil, Vietnam, Canada, Taiwan $(35,000$ to 24,000$)$; Japan, Nigeria, Nepal, Mexico, and Columbia $(16,000$ to 12,000$)$, and the UK, Turkey, Iran, Bangladesh, Germany and Venezuela (11,000 to 9,000) (Global Economic disruptions, 2010). The United States has enrolled more than $1,000,000$ international students yearly. Claims for international student 
education are consistent whether discussed in the United States or in countries around the world.

Issues that are the major foci of the impact of COVID19 on international students include political, social, cultural, and economic implications. Of immediate emphases are students' inability to return home; their reactions to online and virtual learning; their continuing and growing need for housing and food; the social and isolation measures imposed on them; their need for health coverage and mental health help; their reports of insufficient social media and the technologies needed. In addition, barriers to immediate conversions remain to online and virtual learning, when many times course majors are antithetical to such learning methods (q.v. labs, medical and dental courses, biological sciences; physical education). Typical complaints suggest that online courses are not as "good" as onsite or blended learning classes; some see online conversion as abject failures for student use and comprehension. Another student complaint is that of technical adaptability when in reality millions of students have limited reliance on technology due inadequate bandwidth, to class inequalities and poverty among students' resources and overall economic status. Reports confirm that few colleges and universities actually have emergency plans in place (Hunter \& Sparnon, 2018).

\section{CONCLUSIONS/ IMPLICATIONS}

So we can ask: What have we learned about how higher education will change in view of the COVID-19 crises? Higher education administrators are regretting their laggardly attempts at university plans; that they would be better prepared for blended learning; that they would put greater emphases into partnerships with more academic staff and their training; that they would need to employ sanctions about costs reductions for tuitions from students, especially for poorer students; that they would speed up transformation processes now underway; that they will have to confront the large numbers of students who will not return to their campus (from eight Asian markets) which, for example, account for more than $50 \%$ of the total number of international students to the United Kingdom, a three billion pound decline in revenue. In sum, they predict a two to three year disruption of services until a vaccine is developed concurring with the United Nations which warns the virus will "plunge" 500 million people into poverty. They recognize their conservative reactions to the pandemic need reexamination and productive change. They remain unsure and weary that distance education will solve their education production. They remind us 
that institutions of higher education have politically motivated firewalls limiting student access and that student are unenthusiastic and dissatisfied with online learning. They admit that faculty are often weary of distance education and ignore or resent pressure for them to change to online or virtual learning models and in some cases refuse to convert to ambiguous and imposed teaching alternatives. They admit that because of student deference to online learning, the educational revolution is not now and will not later occur. And finally, they explain the post pandemic outlook is bleakest for the poorest, as short, medium, and perhaps even long term consequences and disruptions are inevitable as crises continue (Marinoni, et al., 2020). This projection can focus on Brazil whose pandemic numbers have required closing down all its institutions of higher education.

When surveys are explained concerning internationalization of higher education, often the response is dependent on a particular country's political and economic resources. Data are available but show wide variance on what can be done to mitigate administrators, faculty, and student issues. For example, when asked if the quality of online courses are as good as onsite classes, one fifth of respondents say "it is too early to say," one third of respondents agree that online is as good as onsite class delivery, and one fifth of respondents disagree. Transitions of disciplines to online instruction are another question often asked. Easiest to make transitions to online offerings are reported for Computer Science, Business administration, Social studies, History and Philosophy and the Law (figures of agreement are just above $10 \%$ ). Least easy to make transitions to online delivery are Technology, Physical and Biological sciences, Architectural planning, Veterinary science, Medical and Dental sciences, and Agriculture with respondents explaining they are the hardest to make transitions $(2 \%)$.

In conclusion, what is known about the impact of COVID-19 on international higher education is at best a partial glimpse of the reactions of colleges and universities to the pandemic. Most of the reactions proclaim tentative actions and results, and most reactions are fundamentally lacking in explicit recommendations and plans. We do not know much about the impact of graduation, partial deferment or reductions of tuition for students, or the ability of students to move into jobs or greater education. These positions should not come as a great surprise as neither do our scientists, politicians, or policy makers seem to be any better off. However, concern and fear of greater and continuing endurance of the COVID-19 virus are expected to continue for at least the next few years. 


\section{REFERENCES}

Altbach, P. G., \& de Wit, H. (Winter, 2019). Too Much International Higher Education, (96), 2-3. Routledge.

DAAD (2020). DAADcorona info page https:/www.daad.ee/en/coronavirus/ Harkavy, I., Bergan, S., Gallagher,T., \& van't Land,T. (18 April 2020). Universities must help shape the post-COVID-19 world, https://www.universityworldnews.com/post.php?story=2020041315 2542750

Hunter, F., \& Sparnon, N. (2018). The future agenda for Internationalization into institutional life. Routledge.

Hunter, F., \& Sparnon, N. (2018). Weaving internationalization into institutional life. In Proctor, D. \& Rumbly, L. The future agenda for internationalization in higher education. Routledge.

Marinoni G., \& van't Land, H. The impact of COVID-19 on global higher education (2020) International Higher Education Special Issue 102

Zhou, Y. (2020). How international students are supposed to deal with coronavirus, according to their universities. Global Economic Disruptions.

ROSEMARY GILLETT-KARAM, PhD is an Associate Professor at Morgan State University, Baltimore, MD. Her major area of interest includes research about American and International Community Colleges, their leadership and the mismatches of leadership considering lack of inclusion and diversity; she has written extensively on women in higher education and on international community colleges and their relationships to American community colleges. Email: r.gillett-karam@morgan.edu 